\title{
Orientalism and Re-Orientalism in Yann Martel's Life of Pi
}

\author{
JIANG YUQIN
}

\begin{abstract}
Yann Martel expresses his Orientalism and describes Pi's ReOrientalism in Life of Pi. Martel's Orientalism presents the typical postcolonial writing model, which constructs a postcolonial exotic. Pi's Re-Orientalism reflects a diasporic Eastern boy's desire and identity in the West. The survival story for $\mathrm{Pi}$ and the Bengal tiger is a metaphor for Pi to grow up to be a true western man. Martel uses paratexts such as the author's note, author's interview with the protagonist $\mathrm{Pi}$, records for a Japanese investigation on the truth, and inserts into the protagonist Pi's narration, which expose the hidden intention for latent cultural hegemony. The departure of Richard Parker represents Pi's final conforming to Western culture.
\end{abstract}

Keywords: Orientalism; Re-Orientalism; paratext; postcolonial narration

\section{Introduction}

Orientalism is a key concept for postcolonialism. Said argues that Orientalism is "a Western style for dominating, restructuring and having authority over the Orient" (Said 1979: 3). In the book Orientalism, Said explains how the knowledge of the East was constructed into the paradigm of the Western world by scholars in all kinds of fields. Lau and Mendes follow Said's idea and find a "resurfacing of new manifestations of Orientalism" (Lau \& Mendes 2011: 3) in South Asian writing and cultural production. For Re-Orientalism, Lau and Mendes mainly refer to those narrators and producers with Eastern affiliations. The Orient absorbs and internalizes Orientalism in their productions and stories. Actually, Lau presented the argument two years ago that ReOrientalism is based on how cultural producers with Eastern affiliations come to terms with an Orientalized East, whether by complying with the perceived expectations of a Western reader, by playing with them or by discarding them altogether (Lau 2009: 571-590). For Veena and Ramanathan, "Re-orientalism is a form of indigenized Orientalism whereby the Orient reorientalizes itself" (Veena \& Ramanathan 2013: 2). Therefore, Re-Orientalism dominates and 
distorts the representation of the Orient, consigning it again to a position of Otherness (ibid. 3). Minoli Salgado concludes that Re-Orientalism is a reorientation of diasporic people and their deep anxieties over cultural legitimacy. Moreover, in its most radical form, such a reorientation can prompt a profound revaluation of the position of the diasporic and national subject in ways that provoke a productive dialogue between them. In its most reactionary form, it can work to deepen and entrench the difference generated by the Orientalist discourse itself (Salgado 2011: 199). Therefore the "return" or "repetition" of Orientalism depends on those diasporic people who are located outside the geographical boundaries of the Orient but who are nevertheless connected to this part of the world through ancestral ties (ibid. 200). But my article presents a Re-Orientalism that is not only constructed in the writing of diasporic people with Eastern affiliation, but also a new phenomenon for the western writers to outline new images for Eastern people. This Re-Orientalism is very hard to be found because it hides behind the story of humans and animals, such as in the novel of Life of $P i$.

Life of $\mathrm{P} i$ is a survival story of $\mathrm{Pi}$ and the Bengal tiger Richard Parker when crossing the Pacific Ocean. The author is the Canadian novelist Yann Martel who has no Eastern affiliations. The novel has been written about in terms of the human-animal relationship (Stephen 2010; Huggan \& Tiffin 2010; Bartosch 2013), the shipwreck narrative (Dwyer 2005: 9-21; Wright 2010), trauma (Scherzinger \& Mill 2013: 53-66) and the postmodern survivor narrative (Duncan 2008: 167-183). It has also been shown that there is a close relationship between Life of $P i$ and Robinson Crusoe because of their similar shipwreck narrative and adventure format (Atwood 2002; Beckett 2009; Dwyer 2008; Wright 2010). The adventure of Pi and the Bengal tiger Richard Parker constructs a fantastic paradigm for the relationship of human and animal, the East and the West. But as Wright inquired in Wilderness into Civilized Shapes, we could continue to ask why Martel's protagonist needs to be non-Western in general and Indian in particular, why Yann Martel chooses Pondicherry as the initial setting of the story, why there is a Bengal tiger on the lifeboat in the first story but no animal in the second story. My article argues that the narrative strategy in Life of Pi plays a significant role in representing Orientalism and Re-Orientalism that are hidden behind the story of Pi. The author as an interviewer and the protagonist as an interviewee participate together in the narration at the same time so that it creates a tension enabling the reader to discover that there is a cultural dialogue between Orientalism and Re-Orientalism. 


\section{Exoticism and Exhibition: a Trend for Orientalism}

Graham Huggan explained postcolonial exoticism in The Postcolonial Exotic, where he implied that 'the view of a 'target public' is inevitably reductive and that Midnight's Children is primarily or even exclusively directed at a Western metropolitan audience" (Huggan 2001: 72). Huggan criticized Rushdie's relation to Orientalism, because Rushdie emphasized the ideological shortfall of the self-serving Orientalist myths. Foster explains that "while exoticism describes the systematic assimilation of cultural difference, ascribing familiar meanings and associations to unfamiliar things, it also denotes an expanded, if inevitably distorted, comprehension of diversity which effectively limits assimilation 'since the exotic is [...] kept at arm's length rather than taken as one's own'" (Foster 1982/3: 22; cited in Huggan 2001: 14). Huggan defines exotic as a site of discursive conflict between a local assemblage of more or less related oppositional practices and a global apparatus of assimilative institutional / commercial codes (Huggan 2001: 28). Life of $P i$ is full of this postcolonial exotic. It constructs Pi's memory of Pondicherry and good relationship with animals in the Zoo.

Yann Martel declares India to be an inspirational nation. In the "Author's Note" of Life of $P i$ he writes how India he travelled to Bombay to write his imagined Portugal story in 1939. When his writing met with problems, an old man in an Indian Coffee House on Nehru Street approached him and guided him to find the truth of writing. He states that the story of an Indian boy "will make you believe in God" (Martel 2002: vii).

In the "Author's Note", Martel espouses a typical exoticism of colonial and postcolonial writing. The Oriental image can be charming to meet the demands of the Occident. As Elleke Boehmer demonstrated, the empire was imagined and maintained in the writing of the $19^{\text {th }}$ and $20^{\text {th }}$ centuries. Novels, periodicals, travel writings, scraps of doggerel are all textual exercise. "The colonial officer filing a report on affairs in his district, British readers of newspapers and advertisements of the day, administrators who consulted Islamic and Hindu sacred texts to establish a legal system for British India: they too understood colonization by way of text" (Boehmer 2005: 14). This is one side of Indian images within official texts. In another way, "the triple-decker novel and the best-selling adventure tale, both definitive Victorian genres, were infused with imperial ideas of race, pride and national prowess" (ibid.). In Robinson Crusoe, Treasure Island and Jungle Book, white boys or men explore the world with imperial pride. In this way, the control that Pi has over the Bengal tiger on the lifeboat in the novel is a stereotypical story. Pi's story exposes how an Eastern boy obedient to the imperial power can cope with disaster. 
JIANG

For Pi Partel, India is an imagined nation. Pondicherry is an imagined place, isolated from India. It is a former French colony under the domination of the British Empire. Ashcroft has criticized Indian images when they are exotic, "isolated from their own geographical and cultural contexts, they represented whatever was projected onto them by the societies into which they were introduced" (Ashcroft et al. 2007: 88). Meanwhile Pondicherry is a mixture of French and British control. For Lefebvre (1991: 26), social space is a social product. In Pi's memory, Pondicherry is like a paradise. Pi and his family lead a harmonious life with the animals. People are respectful of the each other's religions. But Foucault has argued that there are utopias and heterotopias in the world. If utopias are not real places, heterotopias are a kind of counter-site, "which are outside of all places, even though it may be possible to indicate their location in reality" (Foucault 1986: 24). Foucault also uses the mirror as an image to describe the mixed, joint experience between utopias and heterotopias. He explains that the mirror image is an unreal and virtual space that opens up behind the surface: "I am over there, there where I am not, a sort of shadow that gives my own visibility to myself, that enables me to see myself there where I am absent: such is the utopia of the mirror" (ibid.). Meanwhile the mirror image is also a heterotopia because the mirror also exists in reality. Pondicherry is a place between reality and unreality. It reflects the colonial history of India but is also an imagined Eden. The Pondicherry Botanical Garden is

a hot and humid place, bathed in sunshine and bright colours. The riot of flowers is incessant. There are trees, shrubs and climbing plants in profusion peepuls, gulmohurs, flames of the forest, red silk cottons, jacarandas, mangoes, jackfruits and many others that would remain unknown to you if they didn't have neat labels at their feet [...] Suddenly, amidst the tall and slim trees up ahead, you notice two giraffes quietly observing you. The sight is not the last of your surprise. The next moment you are startled by a furious outburst coming from a great troupe of monkey, only outdone in volume by the shrill cries of strand birds [...] (Martel 2002: 14)

It is a zoo town. Animals and plants are humans' friends. As Said says, Orientalism is nothing more than a structure of lies or myths which, were the truth about them be told, would simply be blown away: "Orientalism therefore is not an airy European fantasy about the Orient, but a created body of theory and practice in which, for many generations, there has been a considerable material investment" (Said 1979: 5). Deckard thinks paradise "is inextricably linked to the 'long' modernity of the capitalist world-system" (2010: 2), implicated in the discourse of material exploitation and colonization. He 
also stresses that the paradise discourse in literature "must therefore be read through a dual hermeneutic which recognizes their simultaneous ideological and utopian functions" (ibid.). Pondicherry is ultimately a disillusion because the capital system is ruined there and the new Indian government destroys it all. Pi's family has to move to Canada.

The zoo is a place for the exhibition of Indian style. In the realm of local animals, the Bengal tiger is the king. It receives a human name Richard Parker. Thus, Parker is a metaphor for India. He is also a signifier for cannibalism. In a chapter in the second part of Postcolonial Ecocriticism Huggan and Tiffin make a concrete analysis of Christianity, cannibalism and carnivory in Western civilization. They argue that the Western civilization has consistently been constructed by or against the wild, savage and animalistic, and consequently been haunted or 'dogged' by it (Huggan \& Tiffin 2010: 134). On the one hand, the West has its cultural tradition of cannibalism because symbolic cannibalism became the core ritual of Christian practice in the Western cultural history (ibid. 168-170). On the other hand, cannibalism is a metaphor for the suppression of threatening the "other". As Huggan and Tiffin argue, Western civilization is still constructed against the wild, savage and animalistic in the East. Moreover, in the postcolonial context, the treatment of animals is used to "vilify, incriminate or marginalize other human groups" (ibid. 137). In this context cannibalism is savage, uncivilized, and scary. Bartosch has warned us about the simple analogy between the animal and the colonized people: "Zoomorphism on the part of the colonizers has been a powerful tool to degrade the colonized, and a sense of an expanded family of human and nonhuman animals seems to link with claims of the 'bestiality' of the colonized and with racist discourses" (2013: 189). So we should oppose an equation between "oppressed" animals and "oppressed" humans (ibid.). Nevertheless, we cannot deny that there is a cultural metaphor for the relationship between Pi and Parker.

Richard Parker represents India. Parker is a local, wild and dangerous animal. As Pi describes him:

It was a vast and dim cement caveat, circular inshore, warm and humid, and smelling of cat urine. all around were great big cages divided up, by thick, green, iron bars. [...] The cages were empty - save one: Mahisha, our Bengal tiger patriarch, a lanky, hulking beast of 550 pounds, had been detained. (Martel 2002: 33)

Father warned Pi and Ravi that the tiger is very dangerous: "I want you to understand that you are never - under any circumstances - to touch a tiger, 
JIANG

to pet a tiger, to put your hands through the bars of a cage, even to get close to a cage." (Martel 2002: 34) When the father decided to take the whole family to Canada, Parker and all the other Asian animals were to be shipped to America. Said argues that there is a latent Orientalism which is different from manifest Orientalism because of its more or less constant unanimity, stability and durability. People with latent Orientalism "keep intact the separateness of the Orient, its eccentricity, its backwardness, its silent indifference, its feminine penetrability, its supine malleability" (1979: 20) and the Orient is "a locale requiring Western attention, reconstruction, and redemption" (ibid.). The Orient is connected with some special figures in the Occident such as the criminal, the savage, the madman, the woman and the poor. Richard Parker is part of $\mathrm{Pi}$, his Indianness.

\section{Re-Orientalism: Cultural Schizophrenia and Nostalgia for Pi}

On the lifeboat, Pi declares his dominance of Parker and cuts off his Indianness through a territorial war. Jenkins and Barrett, in Schizophrenia, Culture, and Subjectivity, explore schizophrenia in culture (2004: preface, $\mathrm{xv}$-xvii). In the field of postcolonial studies, schizophrenia is concerned with binarism. Ashcroft has explained the term "binarism" in Postcolonial Studies: Key Concepts. He traces it back to the structural linguistics of Ferdinand de Saussure. For Saussure, binarism showed the function of a binary between the signifier and the signified. Binarism also refers to the binary oppositions, such as sun/moon, man/woman, birth/death, and black/white. In postcolonial theories, it denotes "the binary colonizer/colonized and the mimicry, cultural schizophrenia or various kinds of obsession with identity, or will put energy into confirming one or other side of the binarism" (Ashcroft et al. 2007: 19). Bhabha stresses the difference between cultures in a postcolonial space. He writes that postcolonial space "doesn't aggrandize the presence of the West but redraws its frontiers in the menacing, agonistic boundary of cultural difference that never adds up, always less than one nation and double" (1993: 241). In this situation, Bhabha use the word "schizoid" to describe those migrants in the splitting of time and narrative, that is "culture as a strategy of survival is both transnational and translational” (ibid. 247). Bhabha refers to Jameson's understanding of postmodern cultural fragmentation. Jameson speaks of the "schizophrenic disjunction" but Bhabha uses the term rather to express a Conradian dilemma of projecting an international space onto the trace of a fragmented subject (ibid. 307-309). So Bhabha uses the in-between to replace this schizophrenic dilemma. 
This cultural schizophrenia is strongly manifest on the lifeboat of Pi. For survival, Pi struggles and fights with Parker. It is a fight between a human and an animal, but also a fight between a local Indian Pi and Pi who is assimilated into Western culture. As an animal, Parker is wild but can be trained if its nature is understood. On the lifeboat, Pi trains Parker. He uses a whistle to alarm Parker in order to associate his increasing nausea with the shrill cries of the whistle, until Parker is under his control. Pi stays with Parker for 227 days. As a cultural metaphor, Parker is Pi's friend, his soul and his Indianness. So as Pi says, he misses Richard Parker in his later life and still sees him in his dreams.

They are nightmares mostly, but nightmares tinged with love. Such is the strangeness of the human heart. I still cannot understand how he could abandon me so unceremoniously, without any sort of goodbye, without looking back even once. That pain is like an axe that chops at my heart. (Martel 2002: 6)

It is an emotion that usually appears in the diaspora examples. Bartosch discusses narratives that critically question their own status as fiction and that are thus capable of both evoking a sense of human-animal community and formulating a critique of the attempts at doing so. She uses the term "humanimality" to stress the fuzzy borders of species and the transgressive power of imagination (2013: 191). Bartosch's viewpoint offers a rethinking of humanity and its role in environmental studies. But in Pi and Parker's case it is not humanimality but cultural identity.

The lifeboat is an important place for $\mathrm{Pi}$ to make his cultural choice. Place itself is a very important concept in postcolonialism. Ashcroft writes in Postcolonial Studies: Key Concepts: "The concepts of place and displacement demonstrate the very complex interaction of language, history and environment in the experience of colonized peoples and the importance of space and location in the process of identity formation" (2007: 161). He points out that a sense of place may be embedded in cultural history, in legend and language, and be a source of contention and struggle. Such intervention may disrupt a sense of place in several ways, such as by imposing a feeling of displacement on those who have moved to the colonies; by physically alienating large populations of colonized peoples through forced migration, slavery or indenture; by disturbing the representation of place in the colony by imposing the colonial language (ibid.). The sense of land interconnects with cultural history, myth and language, and becomes a debatable concept when colonialism distorts it. Bhabha uses the word "beyond" to refer to the cross-boundary in the introduction to Location of Cultures. He emphasizes that "'beyond' 
signifies spatial distance, $[. .$.$] the barrier or boundary which is unknowable,$ unrepresentable, without a return to the present" (Bhabha 1993: 4). He also finds a global link between colony and metropolis, and thinks of it as central to the ideology of imperialism. As for place, DeLoughrey and Handley explain that "place encodes time, suggesting that histories embedded in the land and sea have always provided vital and dynamic methodologies for understanding the transformative impact of empire and the anticolonial epistemologies it tries to suppress" (DeLoughrey \& Handley 2010: 4).

Thus for Pi, the lifeboat is not only a place for survival, but a cultural separation for his subjectivity. If Pondicherry is a space for Pi to mix the cultures between the East and the West, the lifeboat is a space for Pi to discard his Indianness and Re-Orientalize himself to be a representative of the West.

$\mathrm{Pi}$ and the Bengal tiger fight for territory on the lifeboat. It is interesting to find there are several keywords such as "territory", "tame" and "survival manual" for this war between human and animal. In order to survive, Pi uses pissing, a natural animal way to show his power and authority on the lifeboat.

I had to make him understand that I was the top tiger and that his territory was limited to the floor of the boat, the stern bench and the side benches as far as the middle cross bench. I had to fix in his mind that the top of the tarpaulin and the bow of the boat, bordered by the neutral territory of the middle bench, was my territory and utterly forbidden to him. (Martel 2002:186)

Here Pi's claim for authority on territory is a metaphor for the territorial war between the West and the colonized people in history. Marzec explains the relationship of enclosure and hegemony: "An enclosure is the turning of open, communal land into private property [...] 'Holding land' suggests a logic of one neighbor standing against another. It imposes on the surface of the land a positivist ideology" (2007: 8-9). Enclosure becomes an accepted way of life, private property is protected:

Annexed to the periphery, away from the center of 'proper' culture, the Commons, and the people living on them (gypsies, vagabonds, migrant laborers, displaced farmers), were given an inferior status paralleling the 'uncivilized' and 'wild' indigenous inhabitants of the Americas, Africa, India, and the East Indies. (Marzec 2007: 10)

Marzec uses the text of Robinson Crusoe as an example. Crusoe makes an island his home through cultivating the land, taming wild goats, and making a cave. As Marzec says, "Defoe's interest in cultivation concerns more than 
the domination of land; it is part and parcel of British and Western identity formation." (2007: 13) Marzec also states that Crusoe uses his enclosure to declare his property rights, and is excessively driven to explore new territory. So "it is in this taming of an excessive (nomadic) drive that we find the connection between imperial identity formation, the land, and capitalism. The ability to enclose will become the saving grace, that which will mark the difference between a civilized zeal and a savage rambling" (ibid. 14).

The lifeboat is like an island in the middle of the ocean. As Crusoe utilized his goods and tools from a wrecked ship, Pi is lucky enough to find the massproduced goods. A Bengal tiger in the lifeboat is like a footprint found by Crusoe. In Robinson Crusoe, Crusoe rescued a savage and named him Friday. Friday was trained to be his servant. Pi rescues a Bengal tiger and trains him to be obedient to him. Here territorial occupation and enclosure are a key step for Crusoe and Pi to declare their overlordship. In Life of Pi, enclosure is a way for Pi to control Parker. Pi intervenes in Parker's territory, and cleans Parker's feces: "I made clear to Richard Parker that it was my right, my lordly right, to fondle and sniff his feces if I wanted to... I could feel as much as I felt his balls of excrement in my hand: mastery in the making" (Martel 2002: 234). Is it only a human's authority over the animal? No. It is still the authority of the West over the East. Here the lifeboat on the sea is a metaphor for the third space. In this third space, Pi becomes an in-between boy. He is among animals, humans and animals, states, an insider and outsider of the world. The lifeboat is a key space for Pi's ultimate transformation into a Western person. On the lifeboat, he looks at Richard Parker, trains Richard Parker, and loses Richard Parker, as his Indian self. Finally, he is a Torontonian.

Pi's fight with Parker is a form of Re-Orientalism. The relationship between $\mathrm{Pi}$ and Parker is not only a metaphor for cannibalism in imperial history, as Huggan and Tiffin demonstrated, but also an example for discussing how the Eastern people who migrate to the West and find their identities when they go beyond their geographical and cultural boundaries. Their identity is complicated and hybrid but is ultimately shaped by the Western cultural norms.

Pi's Re-Orientalism is also hidden behind his nostalgia. Usually nostalgia begins in desire, and may well end in truth: "It can, and often does, serve as a key to the multiple pasts that make us who and what we are" (Walder 2011: 3). Walder explained that nostalgia is more than longing and desire for a lost home, place and/or time, but "a longing for an experience-subjectivity in the first place” (ibid. 4). To Walder, postcolonial nostalgia is grounded in insecure idealism or sentimentality, casting a beneficent glow over past suffering. From a positive side, "postcolonial nostalgia admits the past into the present 
JIANG

in a fragmentary, nuanced, and elusive way, allowing a potential for selfreflexivity or irony appropriate for former colonial or diasporic subject trying to understand the networks of power relations within which they caught in the modern world, and beyond which it often seems impossible to move" (ibid. 16).

So Pi's nostalgia is full of typical postcolonial exoticism. When he settles down in Toronto, he misses Pondicherry and the tiger Parker. They are a part of him. Pi's loss of Richard Parker is a symbolic loss of imperial history. Toronto is a promised land. But Pi will always dream of Richard Parker.

\section{Postcolonial Unconciousness: The Myth of Postcolonial Narrative}

Orientalism and Re-Orientalism work together in Martel's narrative strategy. The novel is composed of three parts and an author's note. It creates a dialogue between fiction and non-fiction. In the main part of the novel the author narrates as an interviewer: he walks into Pi's house, listens to and records Pi's story. So the author is an obvious narrator in the story, instead of hiding behind the protagonist. Martel uses an author's note and his interview with Pi to remind the reader that it is a true story. Pi is a real person. Pi has a house, a family and his mixed life in Toronto. Pi narrates his incredible story, which is ultimately confirmed by the Japanese to be a true story. So Pi's story is as true as documentary narration.

Genette uses the term paratext to discuss the relations between different texts and their influence on interpretation. The title, subtitle, preface and postscript work as paratexts so that readers can realize the cross-cultural features of the texts. For Genette, "the paratext is for us the means by which a text makes a book of itself and proposes itself as much as to its readers, and more generally to the public" (1991: 261). Genette reduces the phenomena of paratextuality to one short formula: "paratext = peritext + epitext" (1997: 5) Peritexts are paratexts of the "more typical" category as they are separated from the text by at least a minimum distance, thus attracting the reader's/ viewer's attention to some extent, but at the same time they are characterized by a certain proximity to the text. It stems from a part of the actual text, taking place in a position that is both liminal and prominent, and at the same time it detaches itself from the text to refer to it as a whole, to give it its title. Epitexts are defined as the paratexts that are not found within the covers of an individual work in book form (1991: 344-347). There are some examples such as autonomous publishing house strategies and interviews, debates, comments by the author appearing at a later date in letters, diaries, or other genres or 
media. In Life of Pi, the author's note and author's interview with Mr. Patel work as a paratext.

In one way, Martel is trying to make his postcolonial story real. As he says in the "Author's Note", the book he was writing failed, so he went to India for inspiration. He is trying to convince the reader of the truth of the story of Pi. But in another way, the story seems to be a metaphorical one. It indicates that the author's note and Pi's survival story are both true, but the story of human and animal on the lifeboat is suspicious. Pi's story moves between lies and truth, fiction and nonfiction.

Said uses contrapuntal reading to distinguish between the true text and hidden text (1979: 51). The two stories of Pi have an obvious text and a hidden text. The true slaughter of the people on the lifeboat is hidden in the beautiful story of Pi and Parker. The disappearance of Parker exposes the lies behind the story. Therefore the postcolonial unconscious is represented in these two stories. Pi is eager to get an identity from the West, and to move his Indianness away from himself. Parker leaves him without any hesitation.

Jameson concludes that a literary text has a priority over the political interpretation because "ideologies of the text" construct a straw man or inessential term - variously called the 'readerly' or the 'realistic' or the 'referential' text over against which the essential term - the 'writerly' or modernist or 'open' text, or textual productivity - is defined and with which it is seen as a decisive break" (1981: 17-18). When faced with the certain historical paradox, political unconsciousness would use narration to find an ideal solution because the centre of meta-narrative could solve the problem in sub-text. Thus Martel's postcolonial unconsciousness shows his eagerness to be a true Westerner. As Lazarus has shown, there is a new trend for postcolonialism in the contemporary world, it proposes that capitalism tends to be conspicuous by its absence and the term "imperialism" has tended for the most part to be mobilised for describing a process of cultural and epistemological subjugation (2011: 17). Martel's Life of Pi proves that the West is still gazing at the East in a traditional way.

\author{
Yuqin Jiang \\ jyq@szu.edu.cn \\ School of Humanities \\ Shenzhen University \\ No. 3688 Nanhai Road \\ Nanshan District \\ Shenzhen 518060 \\ P. R. CHINA
}


JIANG

\section{Bibliography}

Ashcroft, B.; Griffiths, G.; Tiffin, H. 2007. Postcolonial Studies: Key concepts. Second edition. London \& New York: Routledge.

Atwood, M. 2002. A Tasty Slice of Pi and Ships. - The Sunday Times, 05.05.

Bartosch, R. 2013. Environmentality: Ecocriticism and the Event of Postcolonial Fiction. Amsterdam \& New York: Rodopi.

Beckett, S. L. 2009. Crossover Fiction: Global and Historical Perspective. New York and London: Routledge.

Bhabha, H. 1993. Location of Culture. London and New York: Routledge.

Boehmer, E. 2005. Colonial and Postcolonial Literature: Migrant Metaphors. Oxford \& New York: Oxford University Press.

Deckard, S. 2010. Paradise Discourse, Imperialism, and Globalization: Exploiting Eden. New York and London: Routledge.

DeLoughrey, E.; Handley, G. B. 2010. Introduction: Toward an Aesthetics of the Earth. - E. DeLoughrey, G. B. Handley eds., Postcolonial Ecologies: Literatures of the Environment. Oxford: Oxford University Press, pp.3-39.

Duncan, R. 2008. Life of Pi as Postmodern Survivor Narrative. - Mosaic, 41 (2), 167183.

Dwyer, J. 2005. Yann Martel's Life of Pi and the Evolution of the Shipwreck Narrative. - Modern Language Studies, 35(2), 9-21.

Foster, S. 1982/3. Exoticism as a Symbolic System. - Dialectical Anthropology, 7, 21-30.

Foucault, M. 1986. Of Other Spaces. [Transl. by J. Miskowiec.] - Diacritics, 16, 22-27.

Genette, G. 1991. Introduction to the Paratext. [Transl. by M. Maclean.] - New Literary History, 22(2), 261-272.

Genette, G. 1997. Paratexts: Thresholds of Interpretation. [Transl. by J. E. Lewin.] Cambridge: Cambridge University Press.

Huggan, G. 2001. The Postcolonial Exotic. London and New York: Routledge.

Huggan, G.; Tiffin, H. 2010. Postcolonial Ecocriticism: Literature, Animals, Environment. London \& New York: Routledge.

Jameson, F. 1981. The Political Unconscious: Narrative As A Socially Symbolic Act. Ithaca: Cornell University Press.

Jenkins, J. H.; Barrett, R. J., eds. 2004. Schizophrenia, Culture, and Subjectivity: The Edge of Experience, Cambridge: Cambridge University Press.

Lau, L. 2009. Re-Orientalism: The Perpetration and Development of Orientalism by Orientals. - Modern Asian Studies, 43(2), 571-590.

Lau, L.; Mendes, C., eds. 2011. Re-Orientalism and South Asian Identity Politics: The Oriental Other within. London and New York: Routledge.

Lazarus, N. 2011. Postcolonial Unconscious, Cambridge: Cambridge University Press.

Lefebvre, H. 1991. The Production of Space. Transl. by D. Nicholson-Smith. Malden, Oxford \& Carlton: Blackwell Publishing.

Martel, Y. 2002. Life of Pi. Toronto: Vintage Canada.

Marzec, R. P. 2007. An Ecological and Postcolonial Study of Literature. New York: Palgrave Macmillan. 
Orientalism and Re-Orientalism in Yann Martel's Life of Pi

Said, E. 1979. Orientalism. New York: Vintage.

Salgado, M. 2011. The New Cartographies of Re-Orientalism. - Journal of Commonwealth Literature, 2, 199-218

Scherzinger, K.; Mill, C. 2013. Allegory, the fantastic and trauma in Yann Martel's Life of Pi. - Scrutiny, 2, Vol. 18, 53-66.

Stephen, G. 2010. Feeding Tiger, Finding Food: Science, Religion, and 'the Better Story' in Life of Pi. - Intertexts, Vol. 14, No.1, 41-59.

Veena, M. S.; Ramanathan, P. V. 2013. New Orientalism in Literature: A Critical Overview. - The Criterion: An International Journal in English, 4, 1-7.

Walder, D. 2011. Postcolonial Nostalgia. New York \& London: Routledge.

Wright, L. 2010. Wilderness into Civilized Shapes: Reading the Postcolonial Environment. Athens \& London: University of Georgia Press. 